\title{
Powering Exploration: The Ares I Crew Launch Vehicle and Ares V Cargo Launch Vehicle
}

\author{
Stephen A. Cook, Project Manager \\ Teresa Vanhooser, Deputy Project Manager \\ Ares Projects \\ Marshall Space Flight Center \\ Huntsville, $A L 35812$
}

\begin{abstract}
[Abstract] The National Aeronautics and Space Administration (NASA)'s Constellation Program is depending on the Ares Projects to deliver the crew and cargo launch capabilities needed to send human explorers to the Moon and beyond. The Ares Projects continue to make progress toward design, component testing, and early flight testing of the Ares I crew launch vehicle, as well as early design work for Ares V cargo launch vehicle. Ares I and Ares $V$ will form the core space launch capabilities the United States needs to continue its pioneering tradition as a spacefaring nation (Figure 1). This paper will discuss programmatic, design, fabrication, and testing progress toward building these new launch vehicles.
\end{abstract}

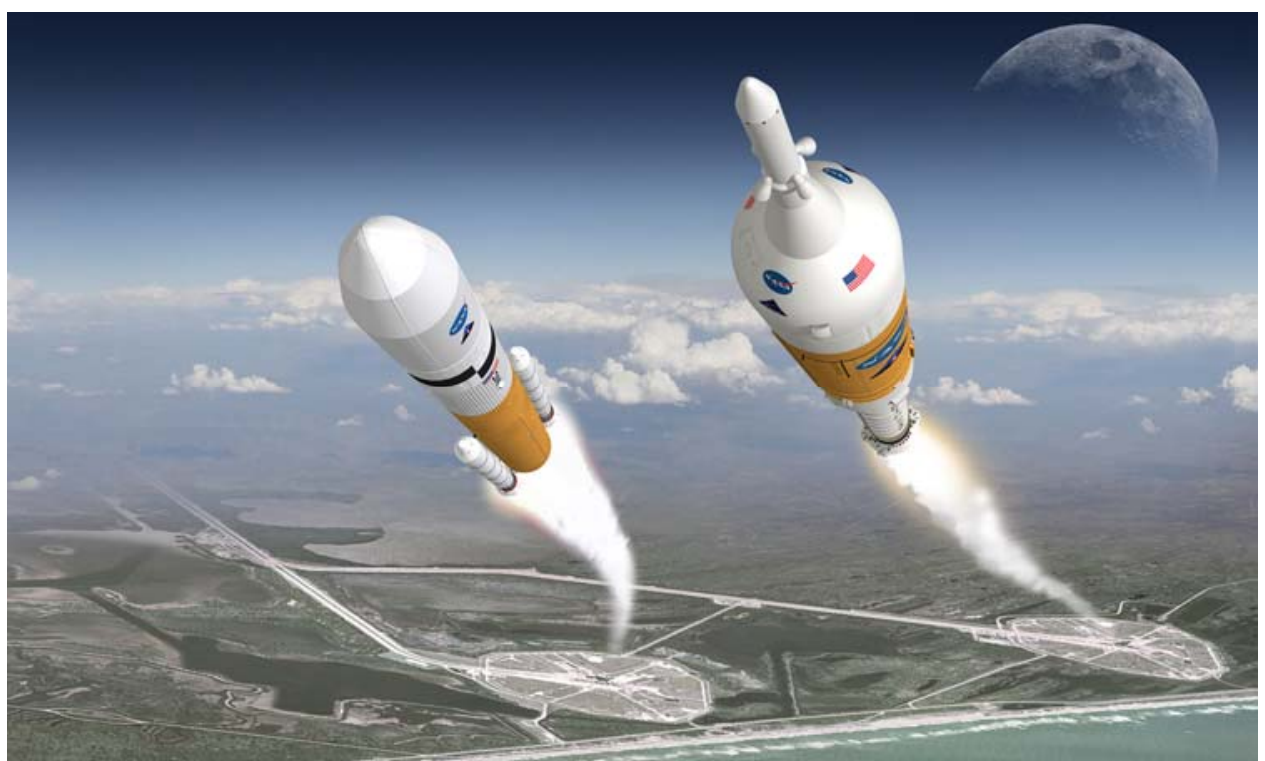

Figure 1. The Ares $V$ cargo launch vehicle (left) and Ares I crew launch vehicle (right) will form the backbone of America's new space fleet. (NASA artist's concept)

\section{Introduction}

The National Aeronautics and Space Administration (NASA)'s Constellation Program is depending on the Ares Projects to deliver the crew and cargo launch capabilities needed to send human explorers to the Moon and beyond. Ares continues to make progress toward design, component testing, and early flight testing of the Ares I crew launch vehicle, as well as early design work for Ares V cargo launch vehicle. Ares I and Ares V will form the core space launch capabilities the United States needs to continue its pioneering tradition as a spacefaring nation. 


\section{2008 Accomplishments}

In 2007 and 2008, the Ares team picked up the pace for design, development, testing, and hardware fabrication of the Ares I crew launch vehicle. This year marks a key milestone for the Ares I: the Preliminary Design Review (PDR), when the project moves from mainly paper studies to a more detailed design and even fabrication of some components. The vehicle PDR is being preceded by element PDRs, which must be passed before proceeding to the integrated PDR in September 2008. The SDR provided a detailed comparison of the established vehicle architecture and the requirements placed upon it by the Constellation Program. This progression toward design and development began last summer when the Ares I Upper Stage Engine, the new J-2X engine, completed its PDR in August 2007. The engine, which began its design cycle much earlier than the rest of the vehicle, also must undergo more testing than any other Ares I element. J-2X will complete its Critical Design Review this fall. Ares was given authority to proceed with the PDR after passing the Ares System Design Review (SDR) in October 2007. The main requirement for the Ares I PDR will be to ensure that the launch vehicle has the performance to carry the Orion crew exploration vehicle to low Earth orbit.

\section{A. First Stage}

As one of the primary, active components of the Ares I-X test flight, the Ares I first stage has already seen some operational hardware designed, fabricated, and tested-particularly the parachute and recovery systems. Because it is based on the existing Shuttle reusable solid rocket motors (RSRMs), the first stage will begin their development schedule earlier than the upper stage engine to maintain the current trained workforce.

The first stage development motor (DM-1), currently being manufactured by ATK Launch Systems and Major Tool, was placed on hold pending resolution of a root cause investigation into propellant voids in a recent shuttle Flight Support Motor (FSM-15). NASA and ATK teams are reviewing data with MSFC technical personnel on-site. An Initial Progress Review is anticipated for June 2008.

\section{Expendability Trade Study}

The first stage office completed a variety of trade studies of the Ares I first stage element, one of which was evaluating the costs and benefits of switching from reusable to expendable boosters. The overall objective of this study was to perform a life cycle cost study to evaluate using an expendable RSRM as opposed to the current reusable RSRM for the Ares I and Ares V first stage boosters. This assessment included evaluating the cost and technical impacts in development, reliability, performance and transition from a reusable to an expendable first stage solution. The study concluded that it was beneficial to continue flying recoverable boosters for Ares I.

\section{Hardware Updates}

The Ares I vehicle may use more composites than any other human-rated launch vehicle. Composites are advantageous because they offer comparable performance for less weight. In June 2007, the first stage team completed a trade study regarding the use of metal versus composite materials for the new forward structures: the forward skirt, forward skirt extension, frustum, and aeroshell (Figure 4). The study focused on reusability, ease of manufacture, structural durability, and weight. The study concluded that composites could be used most effectively for non-reusable structures (the frustum and aeroshell), while aluminum would continue to be used for the recoverable structures (the forward skirt and forward skirt extension). 


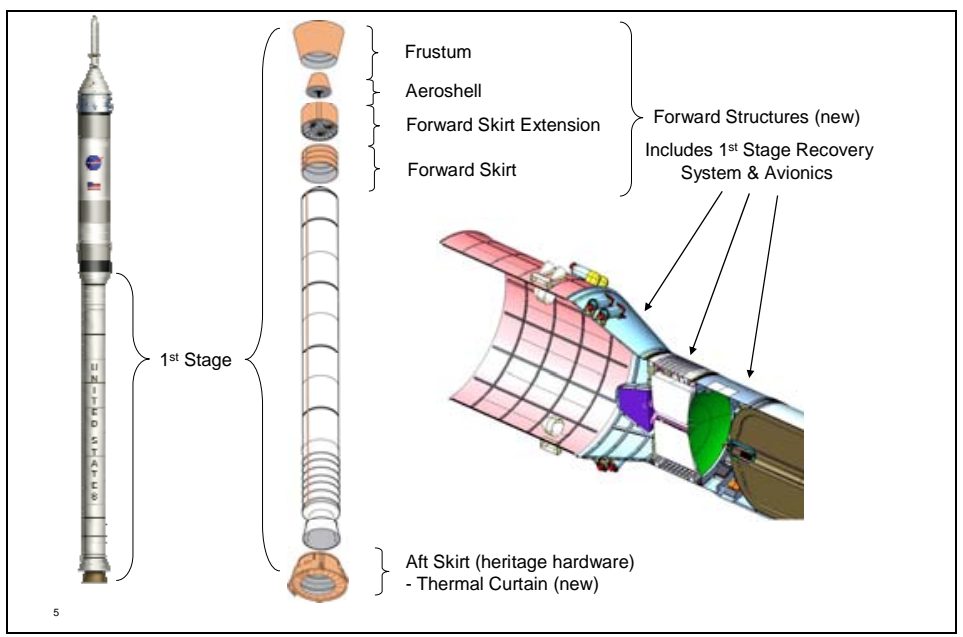

Figure 2. Ares I first stage forward structures.

ATK Launch Systems and their subcontractors are building process simulation articles (PSAs) to help train their work forces in building the new hardware for Ares I first stage components. PSA development enables workers to build and streamline production processes before final production-quality hardware is built (Figure 5). Processes learned and honed in this environment reduce cost and time later. Among the pieces undergoing this work are the mandrels, which are the molds around which propellant is cast for the motor segments.
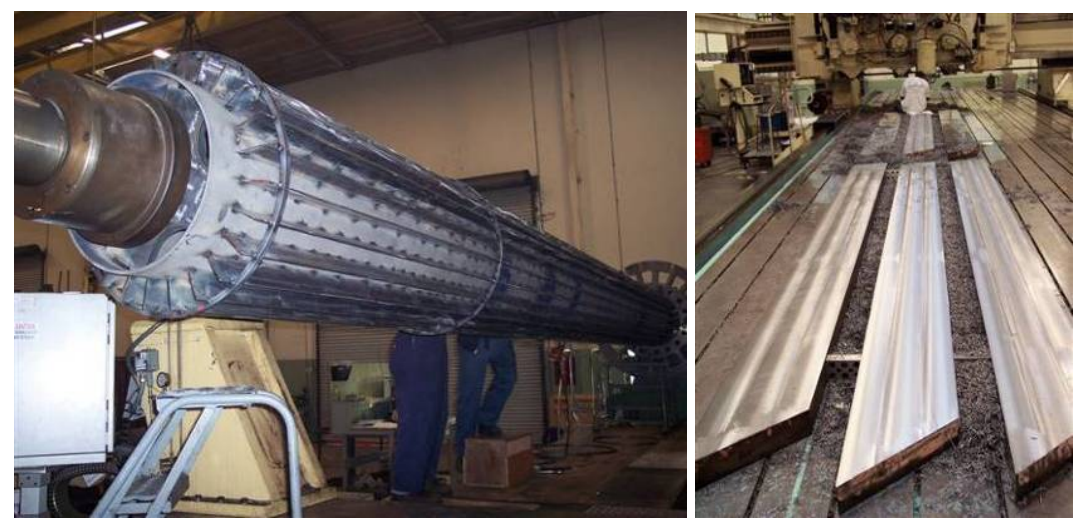

Figure 3. Mandrel process simulation articles are being fabricated.

Manufacturing is underway for the forward structures of the Ares I-X first stage element at Major Tool in Indianapolis, Indiana, who is a subcontractor to ATK, Promontory, Utah. A detailed list of Ares I-X structures, manufacturers, and delivery dates can be found in section II B.

\section{B. Upper Stage}

In 2007, NASA completed contract awards for all the Ares I elements when the agency selected The Boeing Company of Huntsville, AL, as the prime contractor to produce the integrated upper stage and upper stage Instrument Unit (IU) at NASA's Michoud Assembly Facility (MAF) in Louisiana. Components for the upper stage will be manufactured by the prime contractor's suppliers across the country. The final integrated upper stage avionics hardware assembly and checkout will be performed at MAF. Some manufacturing process development and possibly larger assemblies may be performed at Boeing or other supplier facilities.

With a contractor partner on board for the NASA-designed upper stage, Boeing has begun development and production work in earnest. In addition to producing the stages, logistical and shop floor space at MAF are being reorganized to accommodate the transition from the Space Shuttle Program to the Constellation Program, and manufacturing processes and hardware are being developed and tested at MSFC for eventual transfer to MAF. 
The upper stage structure has undergone several design analysis cycles (DACs). These cycles have resulted in design changes, such as the transition to a common bulkhead between the liquid hydrogen $\left(\mathrm{LH}_{2}\right)$ and liquid oxygen (LOX) tanks and the addition of helium pressurization to the tanks. In addition, NASA's Marshall Space Flight Center (MSFC) has taken delivery of a friction stir welding tool, which will be instrumental in developing manufacturing processes for the upper stage and for manufacturing upper stage test articles. One goal is to produce an upper stage with fewer seams and welds because these joining areas are often more apt to have defects or be prone to structural stresses.

The upper stage element team began its PDR the first week of June 2008.

\section{Upper Stage Engine}

The Ares I J-2X Upper Stage Engine is the first exploration-class rocket engine built for a human-rated rocket since the Shuttle Main Engine was developed in the 1970s. It is on the critical path for the vehicle, which means it must complete a series of tests to be qualified for flight. This rigorous testing means the J-2X must stay out in front of the rest of the vehicle development. The engine is being designed to start at altitude and operate for approximately 500 seconds to put Orion into orbit. However, the engine also will be used for the Ares V cargo launch vehicle and it will have to start at altitude, operate for roughly 500 seconds to place the Earth departure stage (EDS) and Altair lunar lander into orbit, shut down for up to 4 days, and then restart for about 300 seconds to execute trans-lunar injection (TLI) before final shutdown. The engine's requirements are summarized in Figure 7 below.

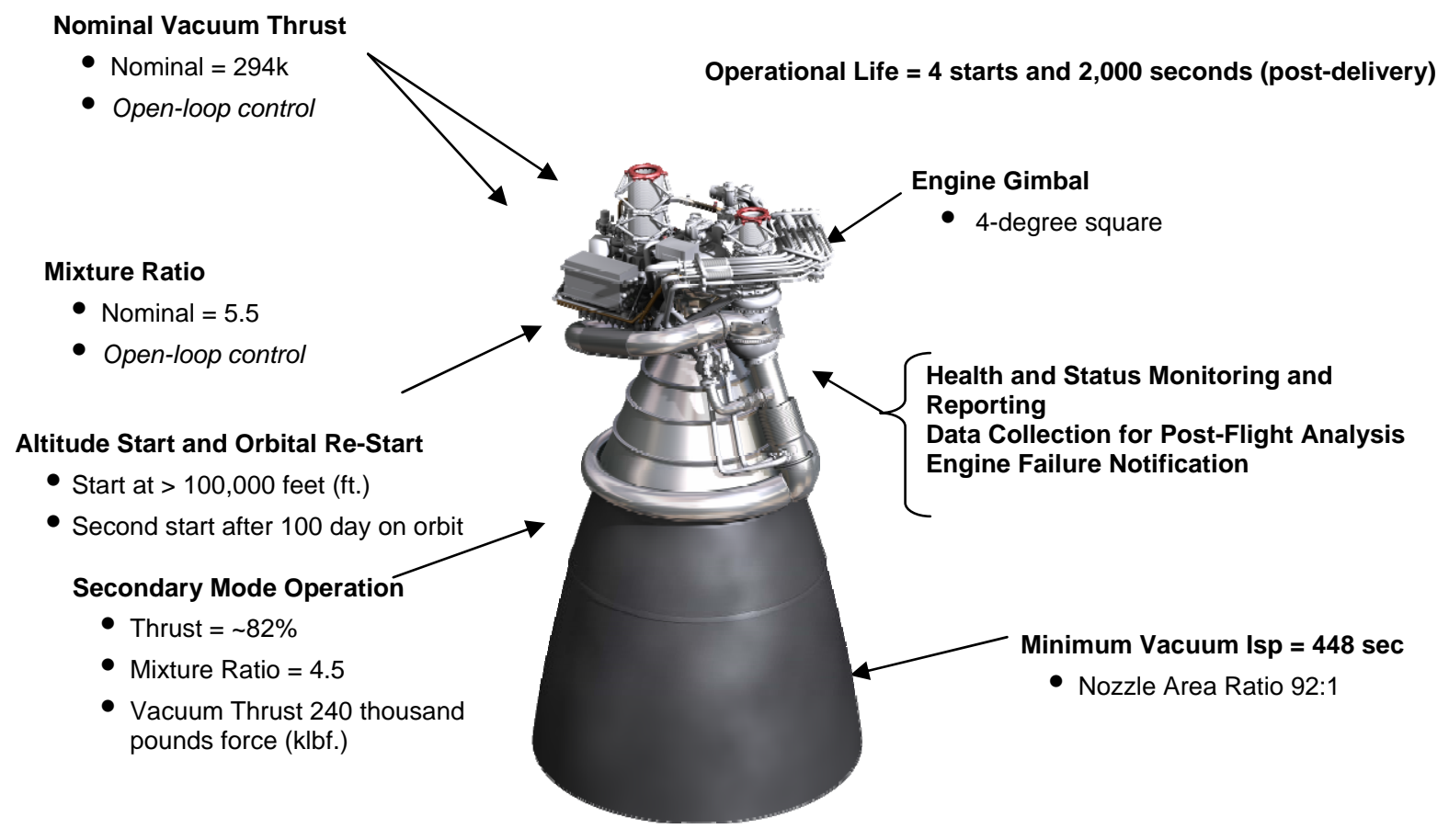

Figure 4. J-2X Key Requirements.

For the last year, the $\mathrm{J}-2 \mathrm{X}$ team has been designing the upper stage engine, testing the turbopump and gas generator powerpack as well as a subscale diffuser, and building a new high-altitude test stand at Stennis Space Center (SSC). 


\section{Powerpack Testing}

The first J-2X powerpack test series began after the powerpack's installation on the A-1 test stand at SSC (Figure 8) in fall 2007, and was completed in May 2008. Test hardware consisted of heritage J-2 turbopumps, gas generator, heat exchanger, spark igniters, helium spin start, and associated hardware from the X-33 program, along with a heritage $\mathrm{J}-2$ crossover duct and thrust chamber. Objectives of this early test series include preparation and testing of the facility, obtaining inducer flow environments, and obtaining pump performance. The turbomachinery development program in 2007 also included water flow testing of existing pump inlets, a turbine air flow test, and water flow tests of the inducers, which provided insights important to planning the powerpack series.

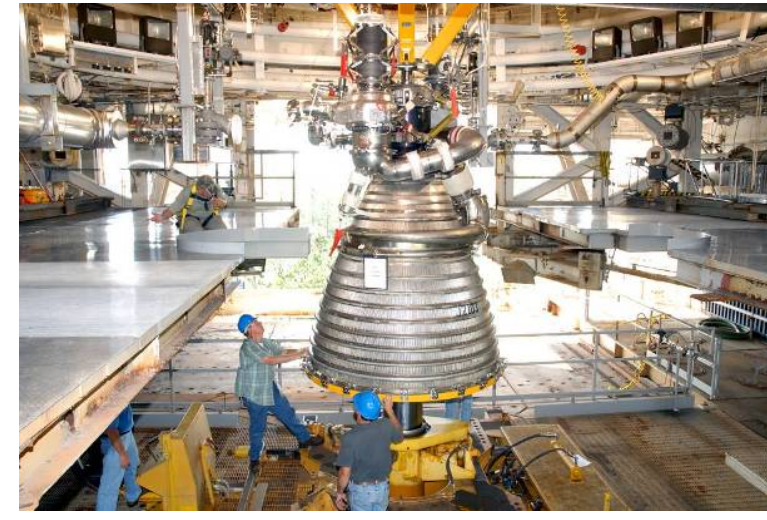

Figure 5. Powerpack 1A during test stand installation at Stennis Space Center.

The SSC A-1 test stand underwent several months of refurbishment and modification to support J-2X testing, and this series provided a good checkout of the facility, test operations and personnel in addition to informing the engine design.

When complete, the government/industry engine team will have more than 1,000 seconds of powerpack operating time at power levels up to an equivalent 274,000 pounds of thrust to inform the design process. The next powerpack series will be in the 2010 timeframe and will employ developmental J-2X turbomachinery instead of heritage $\mathrm{J}-2$ hardware.

\section{Vehicle Integration}

The Ares Project team has a separate element office dedicated to studying and addressing issues that encompass the entire vehicle. The Vehicle Integration function has responsibility for the Ares I integrated vehicle reviews, such as the System Definition Review, which was completed in October 2007, as well as wind tunnel testing for the overall vehicle. To date, the Vehicle Integration team has so far completed 7,000 hours of wind tunnel testing to finalize the Ares I design.

\section{Ares I System Definition Review}

The Ares I System Definition Review (SDR) focused on the current designs for all Ares I elements and compared the predicted performance of each element, as well as the integrated stack, against the baselined requirements. The Ares I SDR had full participation from all Ares elements, the Constellation Program, and all other Constellation sister projects and field Centers involved in Ares work. The objectives of the SDR were to:

- Demonstrate that requirements allocation was complete

- Verify that the design concept/architecture is in compliance with requirements

- Demonstrate that a system that fulfills mission objectives can be built within the constraints imposed

- Demonstrate the system and its operation are well enough understood to proceed towards Preliminary Design Review.

Successful completion of the SDR has enabled the Ares team to progress toward the Ares I PDR, scheduled for September 2008.

\section{1/2\% First Stage Reentry Wind Tunnel Test}

The first stage reentry wind tunnel test of a one-half-percent-scale model of Ares I (Figure 6) helps calibrate the Ares I first stage Altitude Switch Assembly (ASA) or "baroswitch," which deploys the parachute recovery system during reentry. The results will be used to support both Ares I and Ares I-X. Testing was completed at the MSFC Aerodynamic Research Facility (ARF) July through October 2007. Model pressure measurements are made at the 
location of the ASA ports for a wide range of Mach numbers (from 0.4 to 4.00) for different roll positions, and at angles of attack ranging from 90 to 180 degrees.

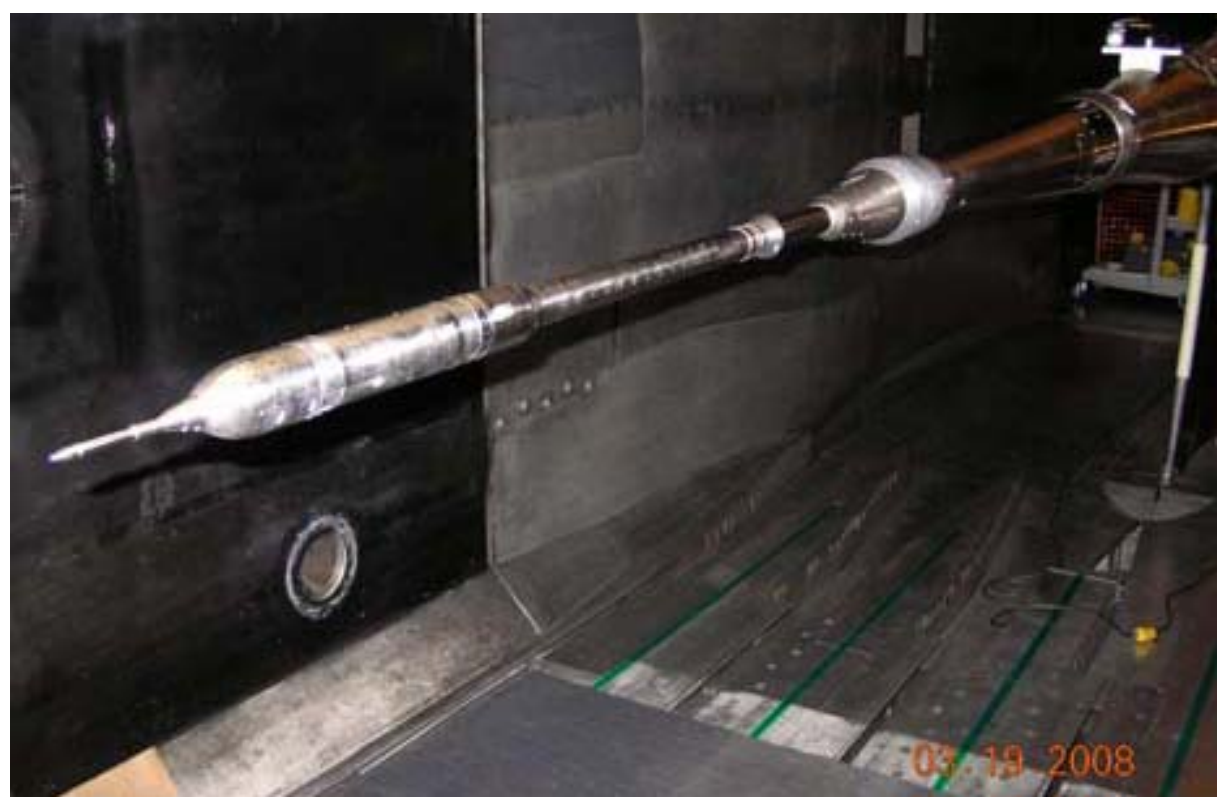

Figure 6. 1\% scale pressure model inside the wind tunnel

The ASA has six pressure ports attached around the First Stage on the outer skin of the Forward Skirt Extension. The wind tunnel team measured pressures at locations on the model, which will define the environment impacting the flight instrumentation. Having a more refined pressure distribution helps determine the optimal location for the six pressure ports and minimize interference effects from protuberances on the vehicle - primarily the systems tunnel and fairing.

The tests were conducted to verify what types of aerodynamic environments the ASAs will encounter when the First Stage re-enters the atmosphere.

\section{Stage Separation Wind Tunnel Test}

This wind tunnel series is investigating the stage separation of the Ares I-X flight test vehicle. The separation event is very important because of the speed at which it occurs: approximately Mach 4.5. The flight of the Ares I-X will allow the design team to better understand all of the aerodynamic properties, relative motions, and other events that will happen during a launch. During the separation event, the J-2X nozzle has to come out, which requires a clean separation without any side movement that could cause an impact with the nozzle. Based on the first stage's speed, altitude, and trajectory, engineers can then determine where it will land. The Ares I-X upper stage simulator will continue upward until it falls into the ocean on a ballistic trajectory; it is not recovered. The actual Ares vehicle would then continue on, taking the astronauts to low Earth orbit.

Langley Research Center (LaRC) has wind tunnels that cover the entire speed regime, from very slow subsonic speeds up to hypersonic wind tunnels. Through all the speed regimes, Ares is trying to improve the flow of the air over a particular vehicle, reshaping the vehicle and comparing the aerodynamic data that we acquire in the wind tunnels with our computational fluid dynamics simulations. LaRC is looking at the control algorithms for the motors that will both tumble the first stage, and control the aerodynamics of the upper stage's flight. The Ares I separation events are different from what Saturn V used for the Apollo missions, so Ares cannot simply redo exactly what the Apollo Program did, but the team can use that historical information as a starting point.

\section{Other Wind Tunnel Testing}

A series of wind tunnel tests at LaRC, Ames Research Center (ARC), and Boeing facilities evaluated the performance of the latest iteration of the Ares I vehicle configuration (ADAC-2B). Tests at ARC evaluated the recently designed active damper system for the Ares I configuration; the Unitary Wind Tunnel Tests performed at LaRC focus on the high speed flow (Mach 1.5 - 4.5); while the Boeing Wind Tunnel Tests focused on the low speed flow (Mach $0.5-1.6$ ). 


\section{E. Facility Upgrades}

In addition to design and development work on the launch vehicles, the Ares team has been building new ground facilities and refurbishing existing assets to meet the needs of the Ares I and Ares V.

\section{A-3 Test Stand Construction}

Progress was made on the construction of the A-3 test at the Stennis Space Center (SSC) in Mississippi. This is the first NASA test stand ever built for altitude testing. The A-3 test stand will perform development and acceptance testing safely on the J-2X engine for the Ares I and Ares V at simulated altitude conditions for full mission duration, including testing the full range of engine gimbal angles. The A-3 stand will be used to conduct both development and certification engine testing, which are important to proving that the J-2X Upper Stage Engine can ignite and operate as required at altitudes of more than 100,000 feet. It will test engine performance at simulated altitudes of 80,000 to 100,000 feet by injecting chemically-generated steam around the test stand enclosure during engine operation, which will evacuate the atmospheric pressure.

A contract was awarded for the steel tower; this test stand uses more steel and less concrete than some of the existing structures at Stennis. Concrete foundations were poured for A-3 as well as for the largest chemical steam system ever built for an engine test stand. A subscale diffuser was built and tested to determine the performance of the diffuser and steam ejector designs for the new A-3 altitude simulation test stand and to alleviate or address any concerns associated with construction of the full-scale test stand.

Site clearing for A-3 began in spring 2007 within hours of approval to build the new test stand (Figure 8). By December, all the structural piles for the foundation had been driven and the concrete forms and reinforcing bars were in place to pour the foundation. In December, 300 truckloads - 3,365 cubic yards - of concrete were poured over a 14-hour period. After it cured, crews poured the foundations for the chemical steam generator tanks and the gaseous nitrogen bottles in the early weeks of January 2008. Work continues on readying the foundation for the tower footings and the steel superstructure to follow. Simultaneously, engineering and business teams are purchasing the structural steel, preparing design packages for the docks and waterways work. The stand is scheduled to be ready for testing in late 2010 .
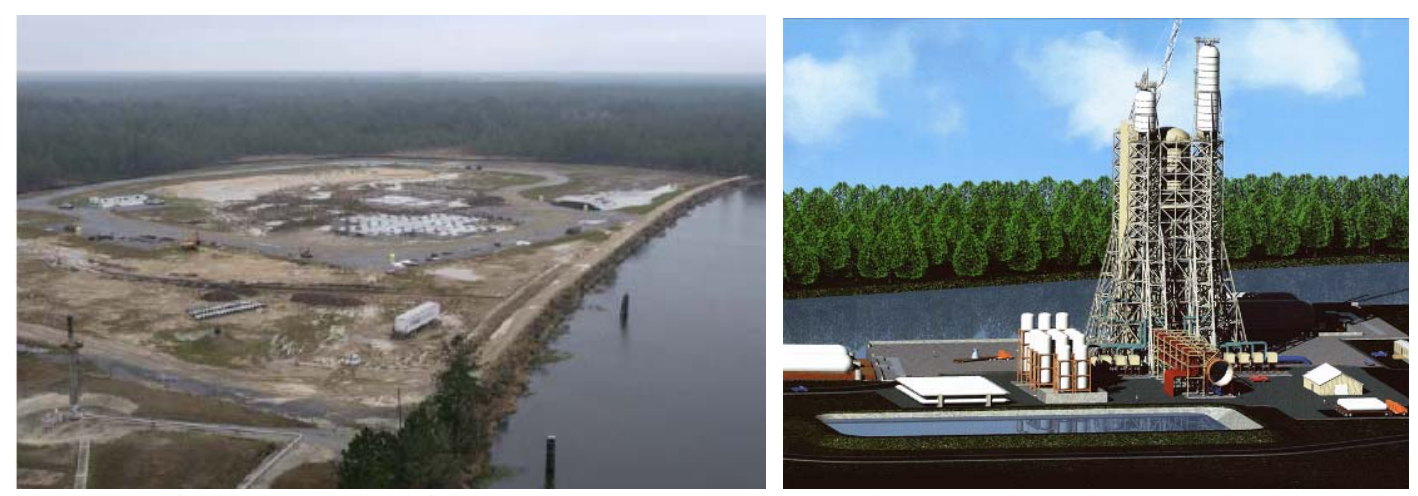

Figure 7. The Stennis A-3 Test Stand site as it appeared in April 2008 (left), and as it will appear in an artist's conception when it is completed in 2010 (right)

\section{Dynamic Test Stand}

Integrated Vehicle Ground Vibration Testing (IVGVT) is scheduled to begin in 2010, and facilities at Marshall Space Flight Center (MSFC) are being refurbished and modified to conduct the first full-vehicle vibration tests since 1979. The IVGVT team completed initial facility modifications to the Dynamic Test Stand, which is the same vibration test stand used for the Apollo Saturn V launch vehicle and integrated Space Shuttle stack.

The three roof panels were removed from the test stand, and the side door, which had an estimated weight of over 71 tons, was opened (lowered), as shown in Figure 7. These procedures were performed by a recently renovated 200-ton derrick crane on the roof. Completion of this effort is a key milestone in the continuing preparation of the Dynamic Test Stand for the Ares I IVGVT. The next activity will be to remove Shuttle-era platforms from the test stand to prepare for modifications later in 2008. 

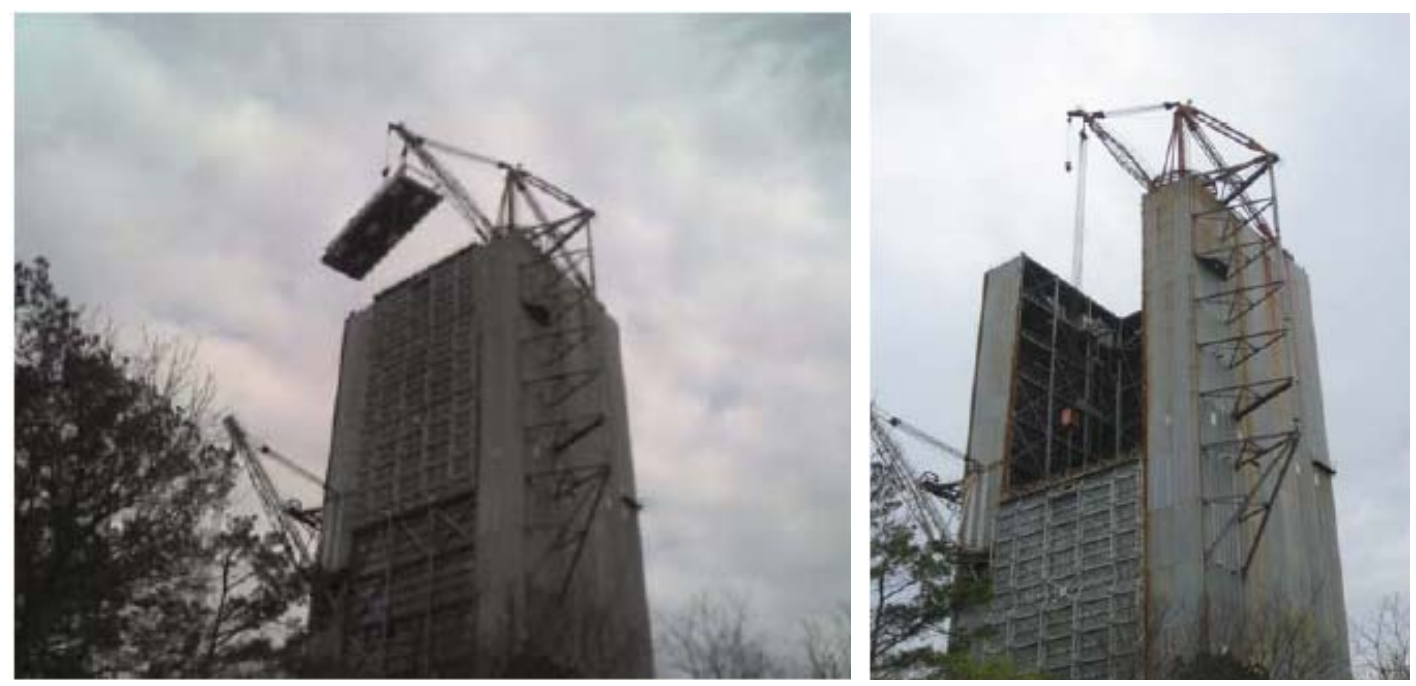

Figure 8. The side door was opened on Test Stand 4550 and the roof panels were removed for the first time in 29 years this past April.

\section{Upper Stage Development Manufacturing}

Marshall Space Flight Center is demonstrating a new robotic weld tool and vertical weld tool to manufacture eight Manufacturing Demonstration Articles (MDAs) of aluminum-lithium gore panels, which will fit together to form the forward dome of the upper stage liquid hydrogen tank. These panels will be used for qualification welds on the robotic weld tool prior to the MDA. A successful MDA will be one where the Manufacturing \& Assembly team has assessed the hardware material properties and manufacturability to a high enough level for design confidence to proceed to the Critical Design Review (CDR) level.

The Robotic Weld Tool (RWT) is a Friction Stir Welding (FSW) tool that will be used to assemble different components of the Ares I Upper Stage in the same manner as was developed under the Shuttle's External Tank program. The RWT is accompanied by a Process Development System (PDS), which performs panel-level development, testing 24" to 26 " long panels before actual hardware is welded in the RWT. The PDS will be used to weld test panels, develop welding process parameters, and troubleshoot welding issues from the larger RWT also installed at MSFC. The PDS was delivered in late August 2007.

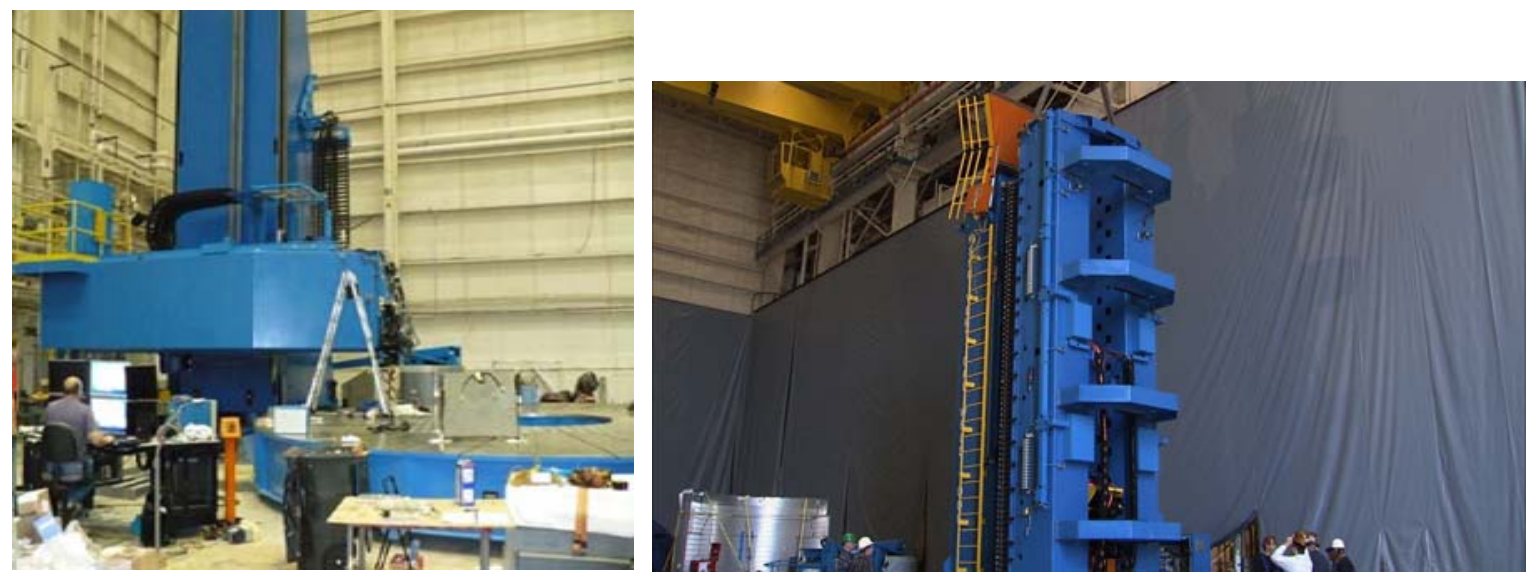

Figure 9. The Ares Projects' Robotic Weld Tool (left) and Vertical Weld Tools (right) are now in place to begin testing upper stage manufacturing processes at MSFC

The Vertical Weld Tool will perform longitudinal barrel welds, used to join several panels together into a barrel section of a tank. This tool, along with the robotic weld tool, provides Ares with an on-site welding facility that is world-class, and will allow the project to test processes and materials prior to flight hardware fabrication at Michoud._The VWT will also be used to help build Upper Stage structural development test articles at MSFC._The 
VWT uses a large anvil and conventional Friction Stir Welding (FSW) technology._Major components began arriving in December 2007, with system checkout currently ongoing.

\section{Upcoming Activities for 2009}

Several element-level reviews and tests will be conducted in the next year as Ares I prepares for its CDR in 2010.

\section{A. Ares I-X Flight Test}

Perhaps the most visible Ares-related activity in 2009 will be the Ares I-X flight test, which will provide the first flight test opportunity for Ares I, demonstrate some of its new ground processes, and provide useful data to inform the vehicle CDR in 2010.

The Ares I-X mission is an uncrewed development test flight to demonstrate the new Ares I crew launch vehicle's flight characteristics; ground, launch, and recovery operations; and roll torque moments. The flight's mission is deliberately designed to obtain important data that cannot be easily obtained through ground test or simulations.

The mission will use a combination of existing, simulator, and off-the shelf hardware to build the vehicle on a relatively short timeline. The Ares I-X vehicle's first stage will consist of an active 4-segment SRB from the Space Shuttle inventory, along with a fifth spacer segment to resemble the full height of the Ares I.

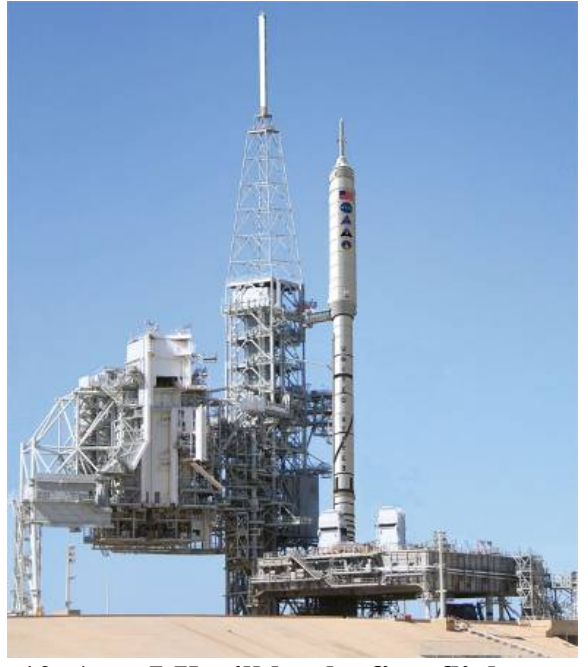

Figure 10. Ares I-X will be the first flight test of the Ares I crew launch vehicle configuration

The first stage forward structures, upper stage, Orion crew exploration vehicle, and launch abort system (LAS) will be mass simulator hardware that matches the outer mold line of the operational vehicle.

Ares I-X is still on schedule to meet its delivery dates to Kennedy Space Center (KSC). Some of the first stage hardware is already at KSC, and many other hardware components will arrive at the launch complex starting in Fall 2008, continuing through early 2009 (Table 1). However, the mission's stacking, integration, and testing activities may be adjusted because of the availability of the Mobile Launch Platform (MLP) assigned to Launch Complex 39B, which must be modified to incorporate Ground Command, Control, and Communications (GC3) hardware for Ares I-X.

Table 1. The Ares I-X vehicle will be a combination of active and simulation hardware developed and manufactured by government and contractor teams at locations nationwide

\begin{tabular}{|c|c|c|}
\hline Element & Manufacturer & Delivery to VAB \\
\hline $\begin{array}{l}\text { Crew Module/Launch Abort System } \\
\text { (CM/LAS) Simulator }\end{array}$ & Langley Research Center & November 2008 \\
\hline Upper Stage Simulator (USS) & Glenn Research Center & October 2008 \\
\hline $\begin{array}{l}\text { Frustum/Forward Skirt } \\
\text { Extension/Forward Skirt }\end{array}$ & Major Tool, Inc. & January 2009 \\
\hline Fifth Segment Simulator (5SS) & Major Tool, Inc. & January 2009 \\
\hline First Stage (first stage) & ATK Launch Systems & October 2008 \\
\hline $\begin{array}{ll}\text { Avionics } \\
\text { - } & \text { Developmental Flight } \\
& \text { Instrumentation (DFI) } \\
\text { - } & \text { First Stage Avionics Module } \\
& \text { (FSAM) }\end{array}$ & $\begin{array}{l}\text { Various Subcontractors under Jacobs } \\
\text { and Lockheed Martin } \\
\text { Lockheed Martin }\end{array}$ & $\begin{array}{l}\text { April-September } 2008 \\
\text { October } 2008\end{array}$ \\
\hline
\end{tabular}

American Institute of Aeronautics and Astronautics 


\begin{tabular}{|l|l|l|}
\hline $\begin{array}{l}\text { Ground Command, Control, and } \\
\text { Communication (GC3) }\end{array}$ & Lockheed Martin & October 2008 \\
- FTINU & Lockheed Martin & March 2009 \\
\hline $\begin{array}{l}\text { Mobile Launch Platform (MLP) } \\
\text { modifications }\end{array}$ & $\begin{array}{l}\text { Kennedy Space Center Ground } \\
\text { Operations }\end{array}$ & February 2009 \\
\hline
\end{tabular}

The Ares I-X successfully passed the first part of a two-part CDR in March 2008 at Langley Research Center (LaRC) in Hampton, VA. The first part of the CDR addressed vehicle structures and propulsion systems. The second part of the CDR, to be held July 22 to 24, 2008, will address flight software, ground systems, and other parts of the vehicle not covered in part one.

\section{B. First Stage Demonstration Motor (DM-1) Test}

Once production issues are addressed, the first five-segment solid rocket motor for the Ares vehicles will be tested at ATK Launch Systems' in Promontory, Utah, static test stand in 2009. This static test will measure burn duration, thrust, and other critical data that will be used to inform subsequent development motors. The first flight of a five-segment motor will be the Ares I-Y flight test in 2012. This will be the first time a motor designed for Ares I has been fired. A static firing was conducted in October 2003 to test a five-segment motor designed in the configuration used by the Space Shuttle, demonstrating that a five-segment motor could be fired successfully.

\section{First Stage Thrust Oscillation}

The First Stage Element Office, in cooperation with the MSFC Engineering Directorate and the Orion Project Office, has been developing design mitigation strategies to overcome a structure oscillation generated by propellant harmonics in the first stage. A variety of approaches are in work on both the Ares and Orion sides of the equation. The combined Constellation team is confident that a mitigation will be identified by the conclusion of the Ares I PDR. Additional data regarding thrust oscillation will be collected by the Ares I-X test flight in 2009.

\section{Ares V Cargo Launch Vehicle}

NASA has begun preliminary concept work on the Ares V cargo launch vehicle. Much of that work is focused on the design of the Earth departure stage, payload shroud, core stage, and the Pratt \& Whitney Rocketdyne RS-68 core stage engines. MSFC is continuing trade studies on the Ares V design, including the optimum shape and size of the composite payload shroud. The size of the shroud will be dictated by the eventual size of the Altair lunar lander, which is still under development by the Altair Project Office. Full-scale Ares V design and development work is scheduled to begin in fiscal year 2011 after the Space Shuttle has been retired in 2010.

Early work on Ares $\mathrm{V}$ has also investigated uses for the cargo launch vehicle not related to human space exploration. These studies have included the launching of very large ("monolithic") science telescopes with an 8meter aperture (Figure 13). Ares V's capabilities would allow astronomers to launch bigger automated observatories to learn more about the formation and evolution of stars and extra-solar planets; look for Earth-like planets and signs of organic molecules suggesting Earth-like life forms; probe the distribution of matter over billions of years; and see matter spiraling around the event horizon of black holes. 


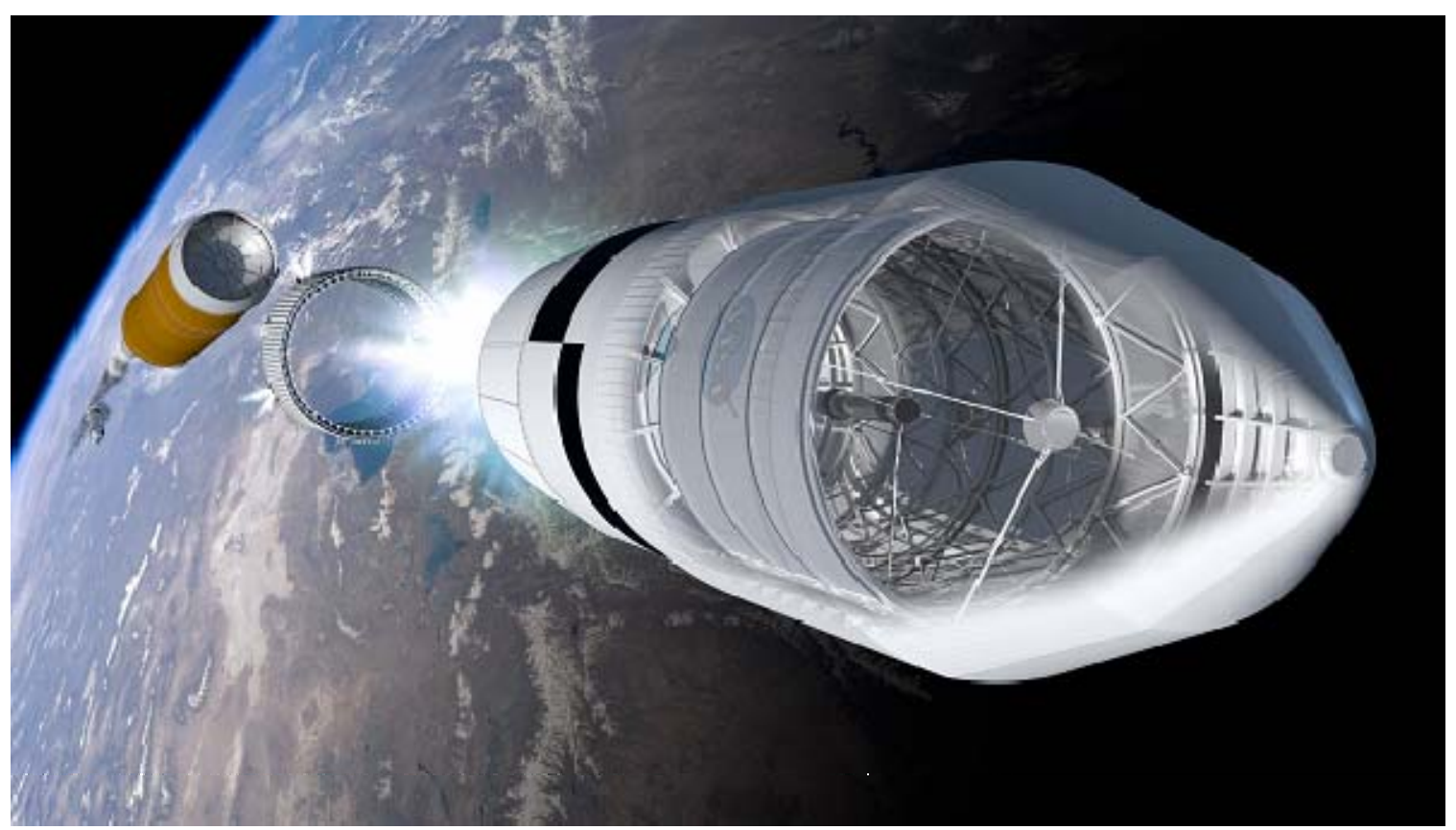

Figure 11. In this artist's conception, Ares V places a monolithic 8-m UV-visual telescope on a path to the Sun

While the biggest commercial rocket today can place about 13,000 kilograms $(\mathrm{kg})$ within a 5-meter fairing into a desirable long-term orbit, Ares V can place 60,000 kg into the same location with an $8.4 \mathrm{~m}$ fairing. Even larger payload shrouds are under consideration, permitting larger optical systems that exceed the capabilities of the amazing Hubble Space Telescope by nearly an order of magnitude.

\section{Summary}

The Ares Projects are making great strides toward building a new generation of launch vehicles to support International Space Station (ISS) operations and-most importantly-human exploration of the Moon, Mars, and other destinations. With the first Ares I flight test in 2009 and additional testing and development work in progress, the Ares launch vehicles continue on schedule to fulfill this strategic capability for the future. This capability will develop in an environment of increasing challenges, as the agency transitions from performing space operations to the more complex, exciting, and dangerous job of expanding the nation's frontiers. 


\begin{tabular}{|c|c|c|c|}
\hline \multicolumn{4}{|c|}{ Nomenclature } \\
\hline$A P O$ & $=$ Ares Projects Office & LAS & $=$ Launch Abort System \\
\hline ASA & $=$ Altitude Switch Assembly & $\mathrm{LH}_{2}$ & $=$ Liquid Hydrogen \\
\hline ATVC & $=$ Ascent Thrust Vector Controller & $L O C$ & $=$ Loss of Crew \\
\hline$B D M$ & $=$ Booster Deceleration Motor & $L O M$ & $=$ Loss of Mission \\
\hline BTM & $=$ Booster Tumble Motor & $L O X$ & Liquid Oxygen \\
\hline $\mathrm{CaLV}$ & $=$ Cargo Launch Vehicle) & LSC & Linear Shaped Charge \\
\hline$C D R$ & $=$ Critical Design Review & MAF & Michoud Assembly Facility \\
\hline CEV & $=$ Crew Exploration Vehicle & Max $G$ & $=$ Maximum Gravity \\
\hline$C L V$ & $=$ Crew Launch Vehicle & $\operatorname{Max} Q$ & $=$ Maximum Dynamic Pressure \\
\hline$C M / L A S$ & $\begin{aligned}= & \text { Command Module/Launch Abort System } \\
& \text { (simulator) }\end{aligned}$ & $\begin{array}{l}\text { MEOP } \\
\text { Mlbf-sec }\end{array}$ & $\begin{array}{l}=\text { Maximum Expected Operating Pressure } \\
=\text { Million pounds of force per second }\end{array}$ \\
\hline$C P$ & $=$ Cylindrical Port & MMO & $=$ Mission Management Office \\
\hline$D A C$ & $=$ Design Analysis Cycle & MPSS & Main Parachute Support System \\
\hline$D D T \& E$ & $\begin{aligned}= & \text { Design, Development, Test, and } \\
& \text { Evaluation }\end{aligned}$ & $\begin{array}{l}M S F C \\
m T\end{array}$ & $\begin{array}{l}=\text { Marshall Space Flight Center } \\
=\text { Metric Ton (Tonne) }\end{array}$ \\
\hline DFI & $=$ Developmental Flight Instrumentation & NASA & $=$ National Aeronautics and Space \\
\hline$D M$ & $=$ Development Motor & & Administration \\
\hline$D T V$ & $=$ Drop Test Vehicle & $P B A N$ & $=$ Polybutadiene Acrylonitrile \\
\hline EDS & $=$ Earth Departure Stage & $P D R$ & $=$ Preliminary Design Review \\
\hline EELV & $=$ Evolved Expendable Launch Vehicle & PFI & $=$ Post Flight Inspection \\
\hline ELP & $=$ Exploration Launch Projects & PSA & Production Simulation Article \\
\hline ESAS & $=$ Exploration Systems Architecture Study & $p s f$ & $=$ Pounds per square foot \\
\hline ETR & $=$ Eastern Test Range & psi & $=$ Pounds per square inch \\
\hline FCDC & $=$ Flexible Confined Detonating Cord & RoCS & $=$ Roll Control System \\
\hline FITO & $=$ Flight and Integrated Test Office & $R S R B$ & $=$ Reusable Solid Rocket Booster \\
\hline first stage & $=$ first stage & $S D R$ & $=$ System Design Review \\
\hline FSE & $=$ Forward Skirt Extension & $\mathrm{sec}$ & $=$ Seconds \\
\hline FSM & $=$ Flight Support Motor & $S O M D$ & $=$ Space Operations Mission Directorate \\
\hline ft. & $=$ Feet & $S R M$ & $=$ Solid Rocket Motor \\
\hline FTINU & $=$ Flight Test Inertial Navigation Unit & SSME & $=$ Space Shuttle Main Engine \\
\hline FTS & $=$ Flight Termination System & SW & $=$ Space Wing \\
\hline GN\&C & $=$ Guidance, Navigation, and Control & $T L I$ & $=$ Trans-Lunar Injection \\
\hline IS & $=$ Interstage & TPS & $=$ Thermal Protection System \\
\hline ISS & $=$ International Space Station & TVC & Thrust Vector Control \\
\hline JSC & $=$ Johnson Space Center & upper stag & $=$ Upper Stage \\
\hline$k$ & $=$ Thousand & USE & $=$ Upper Stage Engine \\
\hline $\mathrm{kg}$ & $=$ Kilogram & USS & $=$ Upper Stage Simulator \\
\hline Klbf. & $=$ Thousands of Pounds of Force & $V \& V$ & $=$ Validation and Verification \\
\hline KSC & $=$ Kennedy Space Center & & \\
\hline
\end{tabular}

American Institute of Aeronautics and Astronautics 
Stephen A. Cook, Ares Projects Manager

Teresa Vanhooser, Ares Projects Deputy Manager

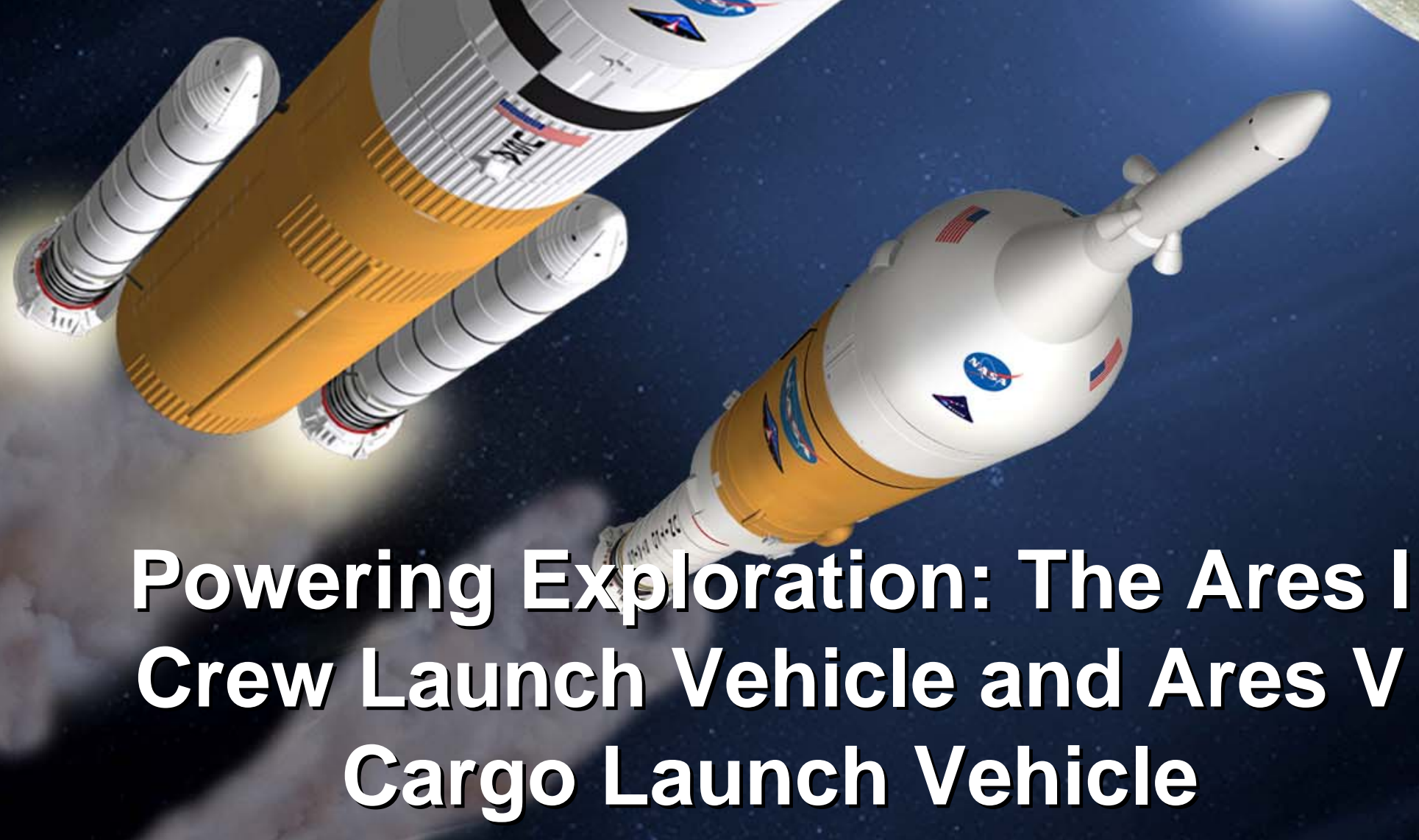




\section{Agenda}

$\checkmark$ Projects Overview

$\Delta$ Projects Status

$\checkmark$ Ares I Changes Since February 2006

$\rightarrow$ First Stage

$\checkmark$ Upper Stage

$\checkmark$ Upper Stage Engine

$\checkmark$ Vehicle Integration

$\checkmark$ Facility Upgrades - Structures and Dynamics

$\diamond$ Ares I-X Flight Test

$\checkmark$ Upcoming Activities

$\checkmark$ Ares V Cargo Launch Vehicle

- Summary I Q\&A 


\section{Projects Overview}

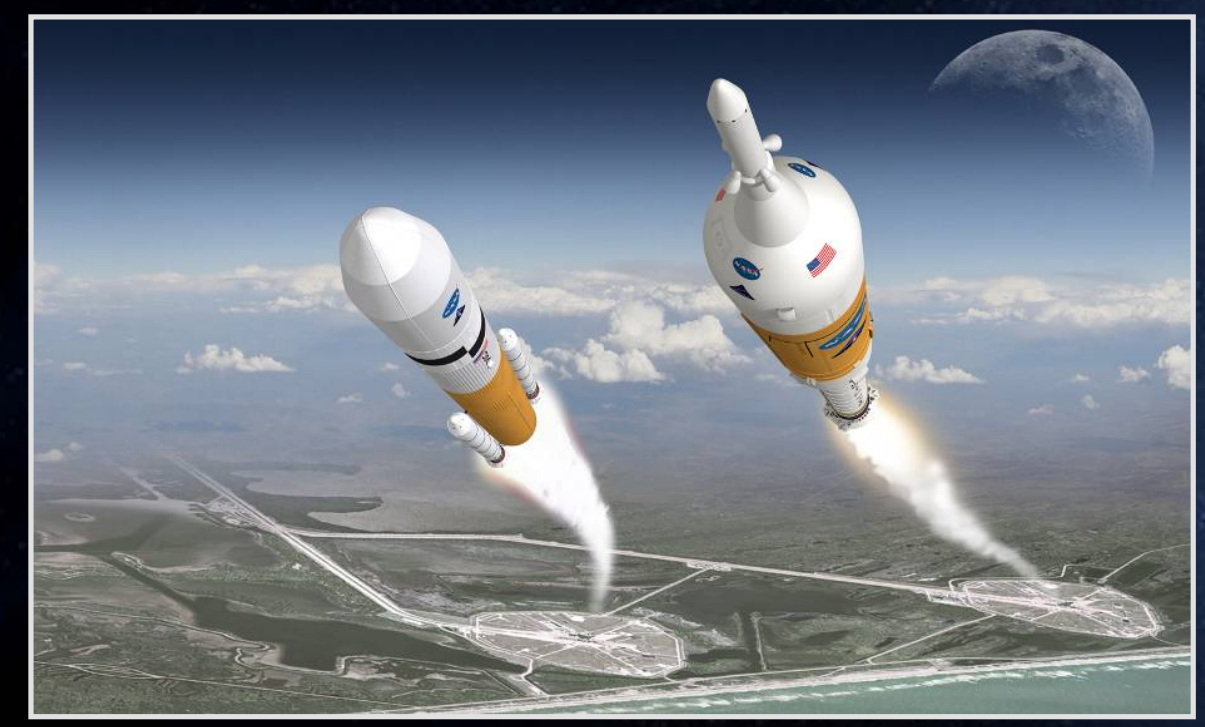

Deliver crew and cargo for missions to International Spac:e Station (ISS) and to Moon and beyond

Continuing progress toward design, component testing, and early flight testing

\section{Ares I Crew Launch Vehicle}

o. Will carry 6 crew to ISS, 4 to Moon

- First flight test 2009

- Initial Operational Capability 2015

\section{Ares V Cargo Launch Vehicle}

- Will launch Earth Departure Stage (EDS) and Altair lunar lander to low Earth orbit for lunar missions

- Largest launch vehicle ever designed

- Will begin detailed development work in 2011 


\section{Projects Status}

Ares I successfully completed System Requirements Review (SRR) and System Definition Review (SDR)

Ares I Preliminary Design Review (PDR) September 2008

\ Element-level PDRs summer 2008

J-2X Upper Stage Engine Critical Design Review (CDR) autumn 2008

Ares I-X flight hardware deliveries focused on April 2009

- Ares V Request for Information (RFI) release July 9, 2008 and response due August 4, 2008 


\section{Ares I Configuration Progression}

Vehicle design and flight profile adjusted to accommodate new Alternate Launch Abort System (ALAS 11) and Encapsulated Service Module (ESM) separation panels

New common bulkhead upper stage propellant tanks

Modified First Stage Booster (FSB) forward skirt

- FSB separation motors moved to aft skirt

\ Single fault tolerant avionics 


\section{First Stage}

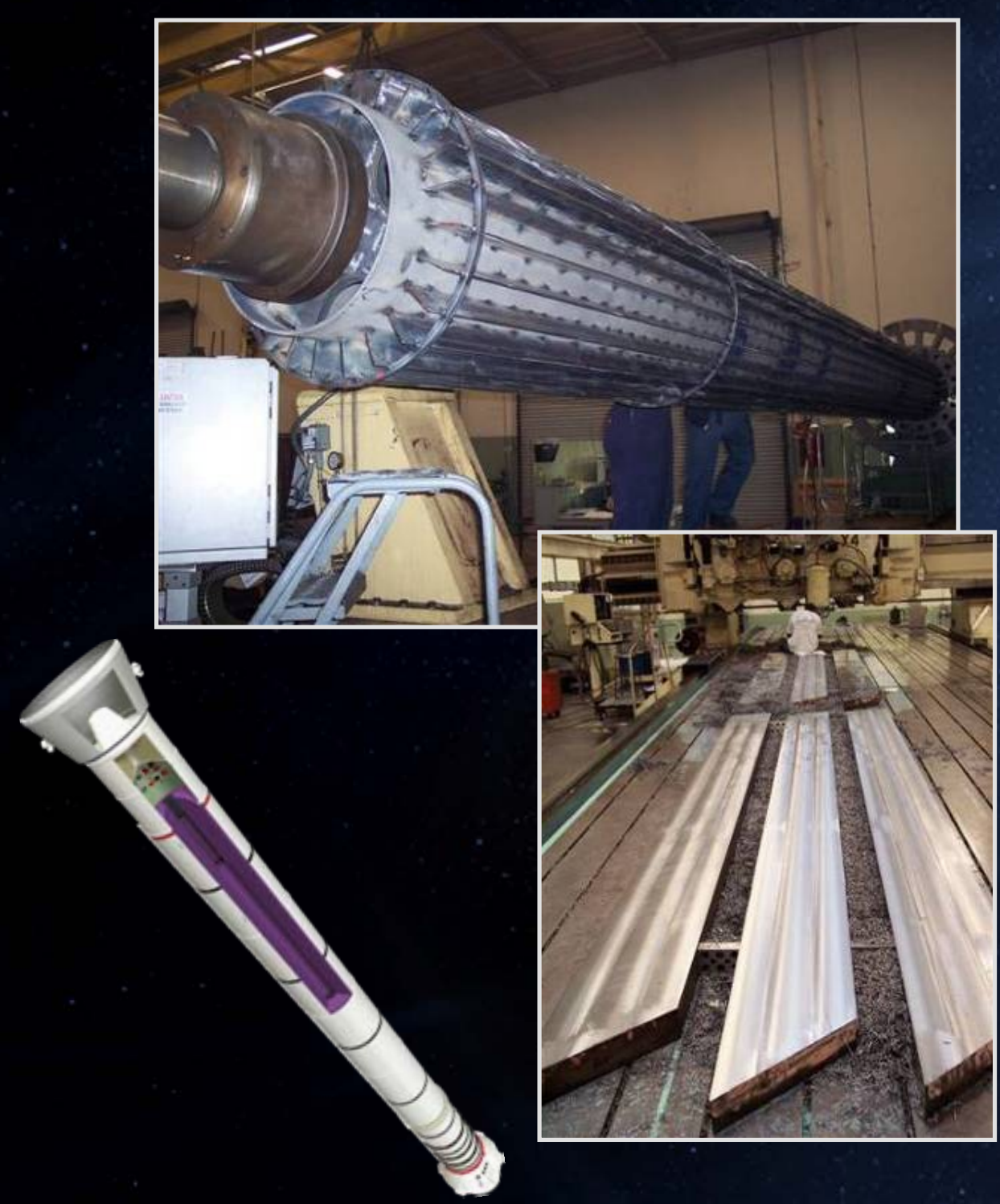

5-segment reusable solid rocket motor based on Shuttje 4-segment motor

Primary propulsion for Ares I, part of Ares V first stage propulsion

Fabrication of Development Motor (DM-1) and process simulation articles underway

Expendability trade study - will continue recovering/reusing motor

Composite hardware for nonreusable structures, metal for reusable structures 


\section{Upper Stage}

Instrument Unit (Modern Electronics)

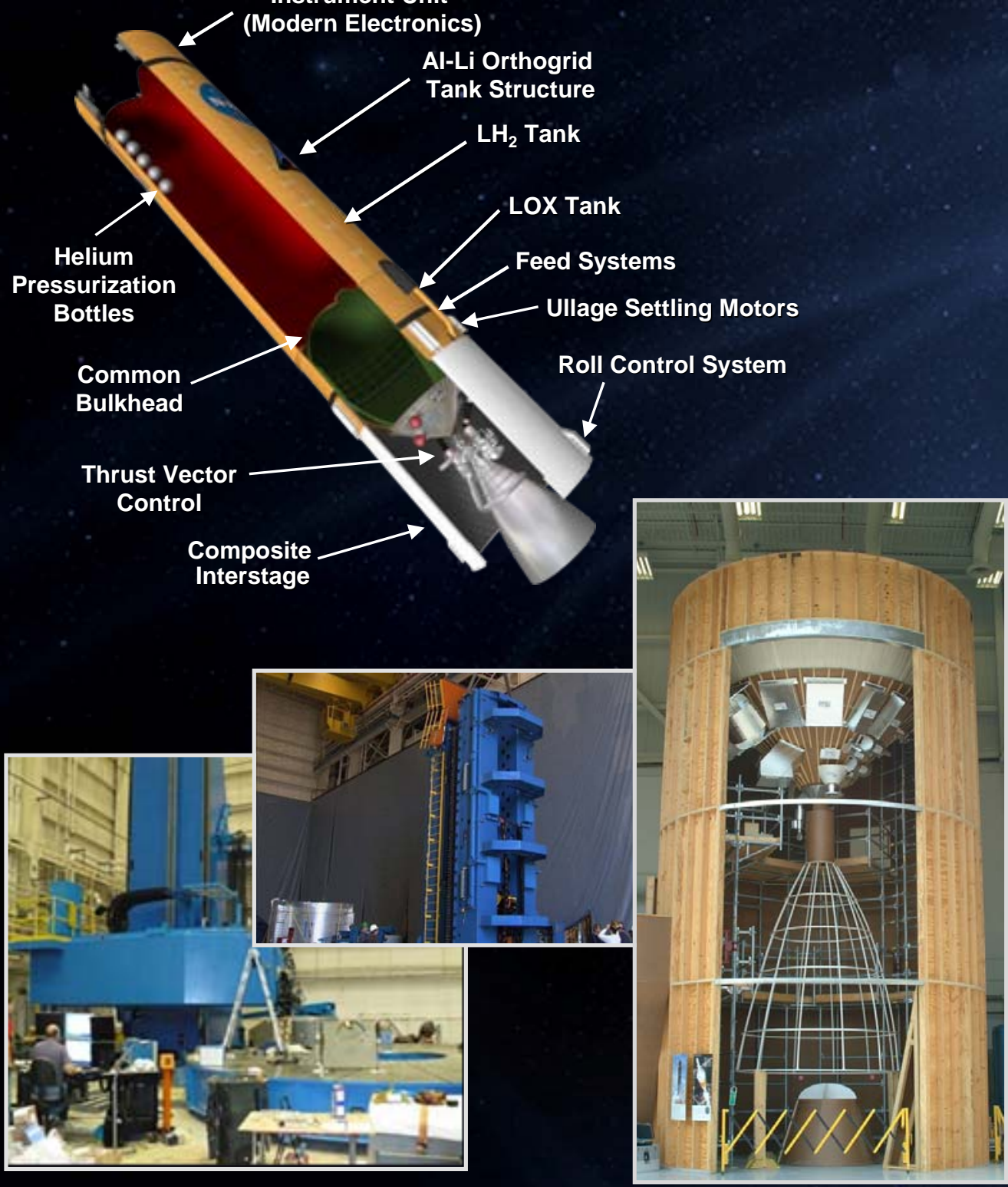

Prime contractor selected for upper stage production and instrument unit

Initial units manufactured at Marshall Space Flight Center (MSFC), production units at Michoud Assembly Facility (MAF)

Main Propulsion Test Article (MPTA) to be tested at MSFC

PDR kick-off June 2008

Using State of the Art CAD modeling to support design and production system

Demonstrating new robotic weld tool and vertical weld tools at MSFC

Will be used to manufacture Manufacturing Demonstration Articles (MDAs) of Aluminum-Lithium (Al-Li) gore panels for Ares I upper stage

- Robotic weld tool is high-precision friction stir welding tool for welding dome portions of upper stage tanks

4 Vertical weld tool will perform longitudinal barrel welds

System checkout currently ongoing 


\section{Upper Stage Engine}

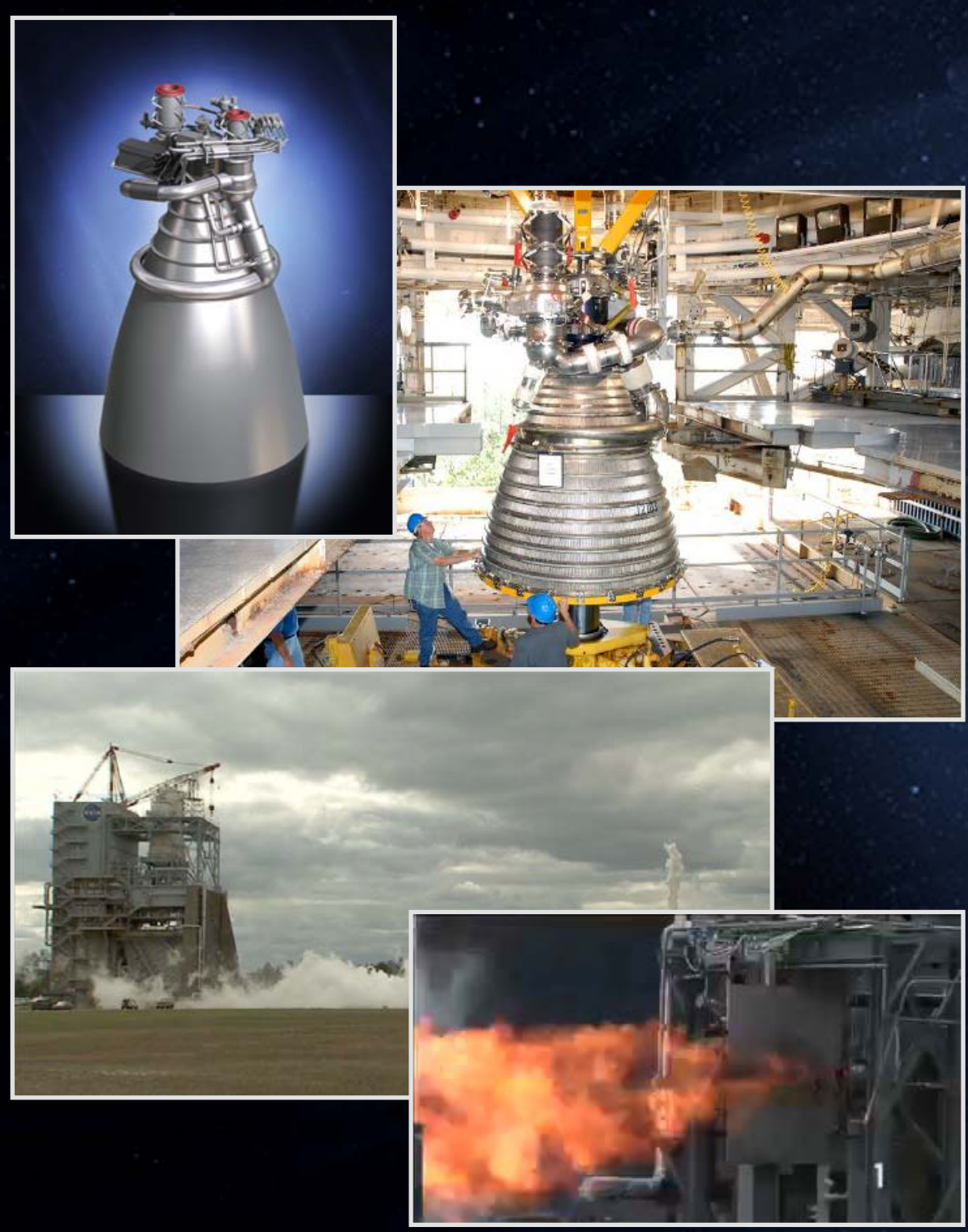

Provides upper stage propulsjon for Ares I and Ares V as well as trans-lunar injection burn for lunar missions

Derived from Saturn V secondand third-stage engines, but incorporates technologies from RS-68 and Space Shuttle Main Engines

Engine in design

Testing turbopump and gas generator powerpack at Stennis Space Center (SSC)

Testing gas generator at MSFC

, Testing subscale diffuser

Building altitude test stand at SSC 


\section{Vehicle Integration}

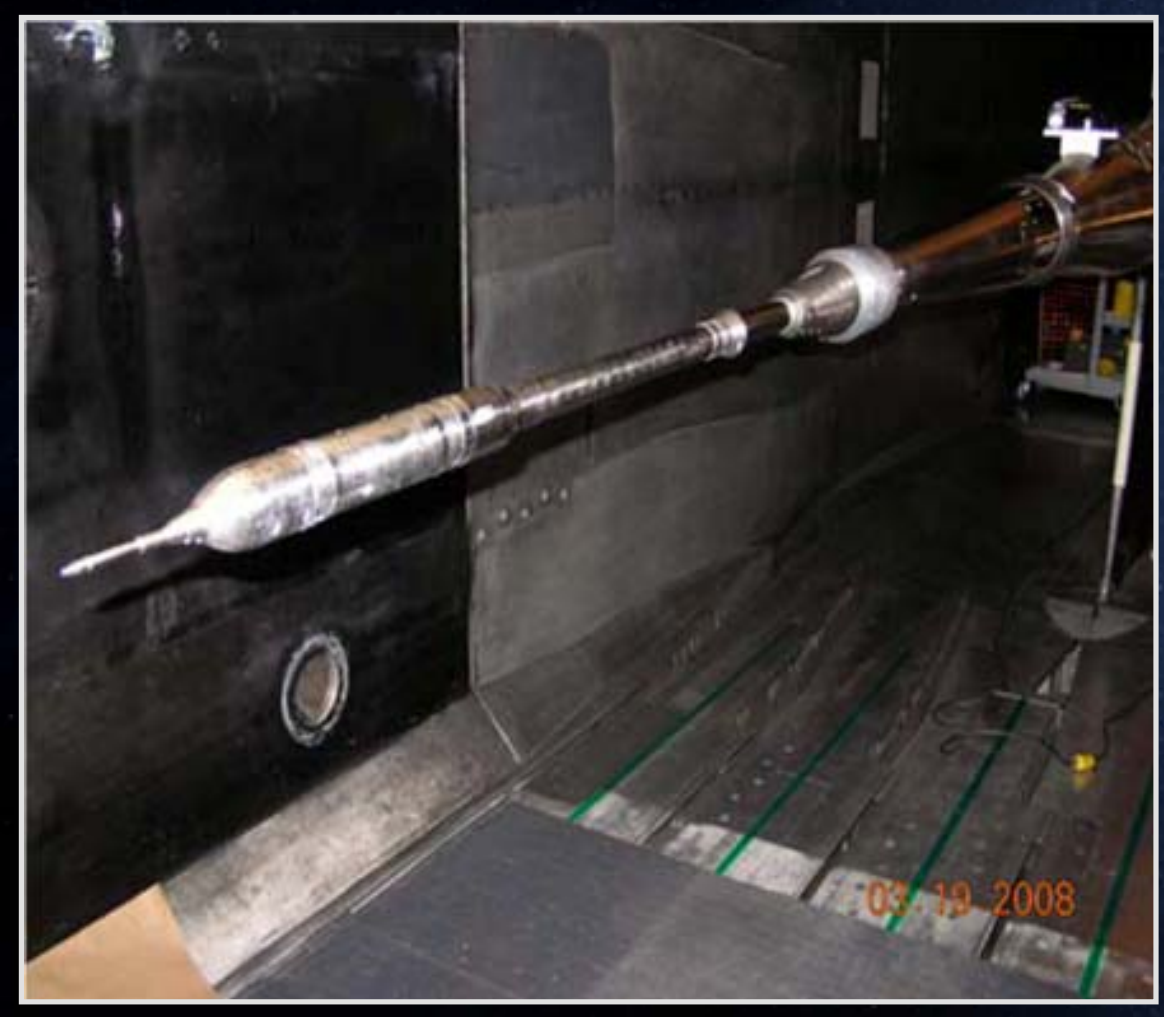

Responsible for Ares I integraired vehicle reviews, including SDR, completed October 2007

Conducting wind tunnel testing for overall vehicle

Conducted 6,000 hours of wind tunnel testing ( $\sim 70 \%$ of planned development testing)

\section{1/2\% First Stage Reentry Wind} Tunnel Test

- Helps calibrate Ares I first stage Altitude Switch Assembly (ASA) or "baroswitch," which deploys parachute recovery system

\section{Stage Separation Wind} Tunnel Test

- Allows design team to better understand aerodynamic properties, relative motions, and other events

\section{Other Wind Tunnel Testing}

- Evaluated high-and low-speed aerodynamic flows 

Structures and Dynamics

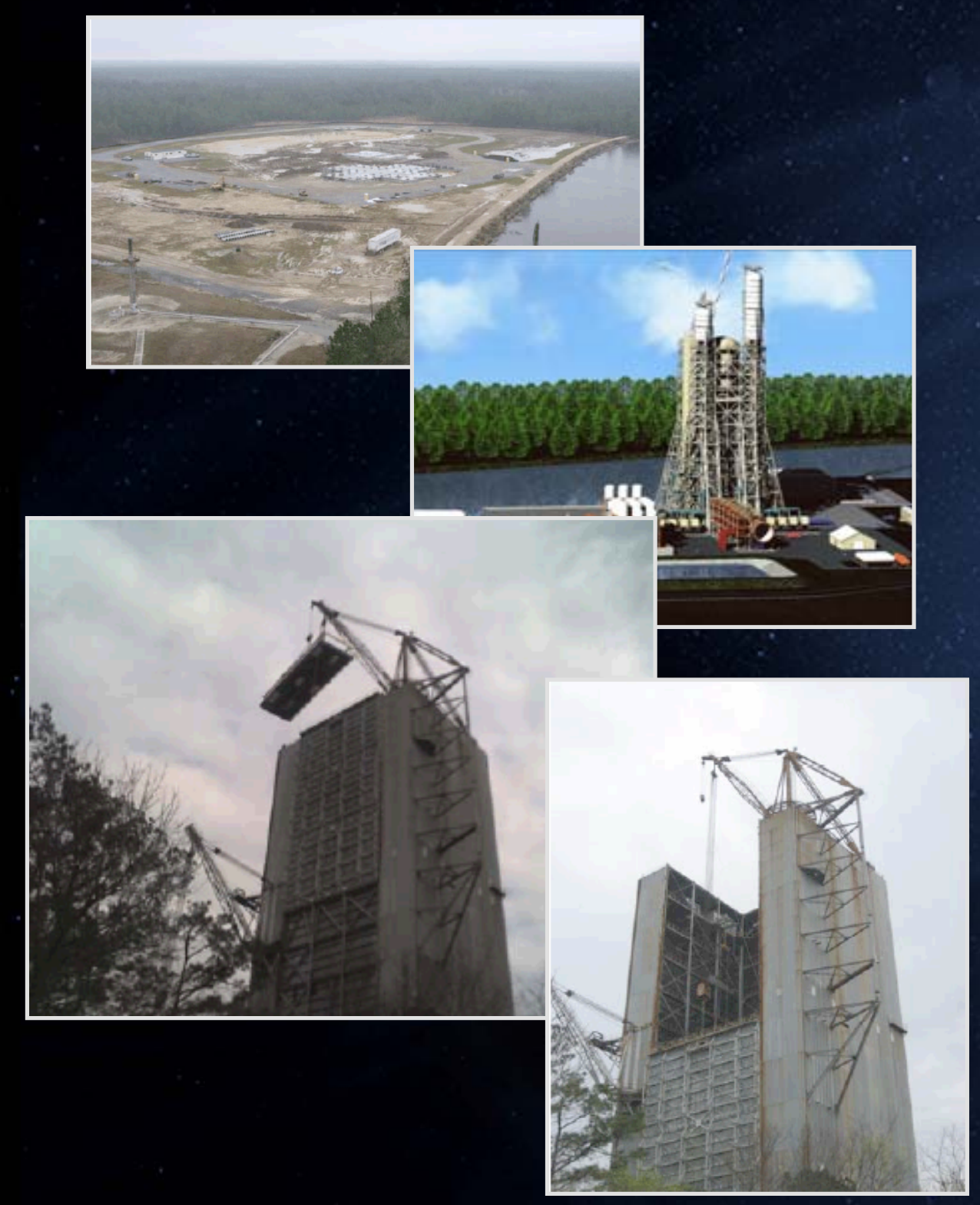

SSC A-3 Test Stand

- First NASA test stand ever buili for altitude testing

- Will be used to conduct development and certification engine testing

- Tests engine performance at simulated altitudes of 80,000 100,000 feet

- Site clearing began in spring 2007

- Structural piles driven and concrete forms and reinforcing bars in place to pour the foundation

\section{MSFC Dynamic Test Stand} Refurbishment

- Used to test Saturn and Shuttle

- Will be used for Ares I and V Integrated Vehicle Ground Vibration Testing

- Upgrading cranes and interior for use in 2011 


\section{Ares I-X Test Flight}

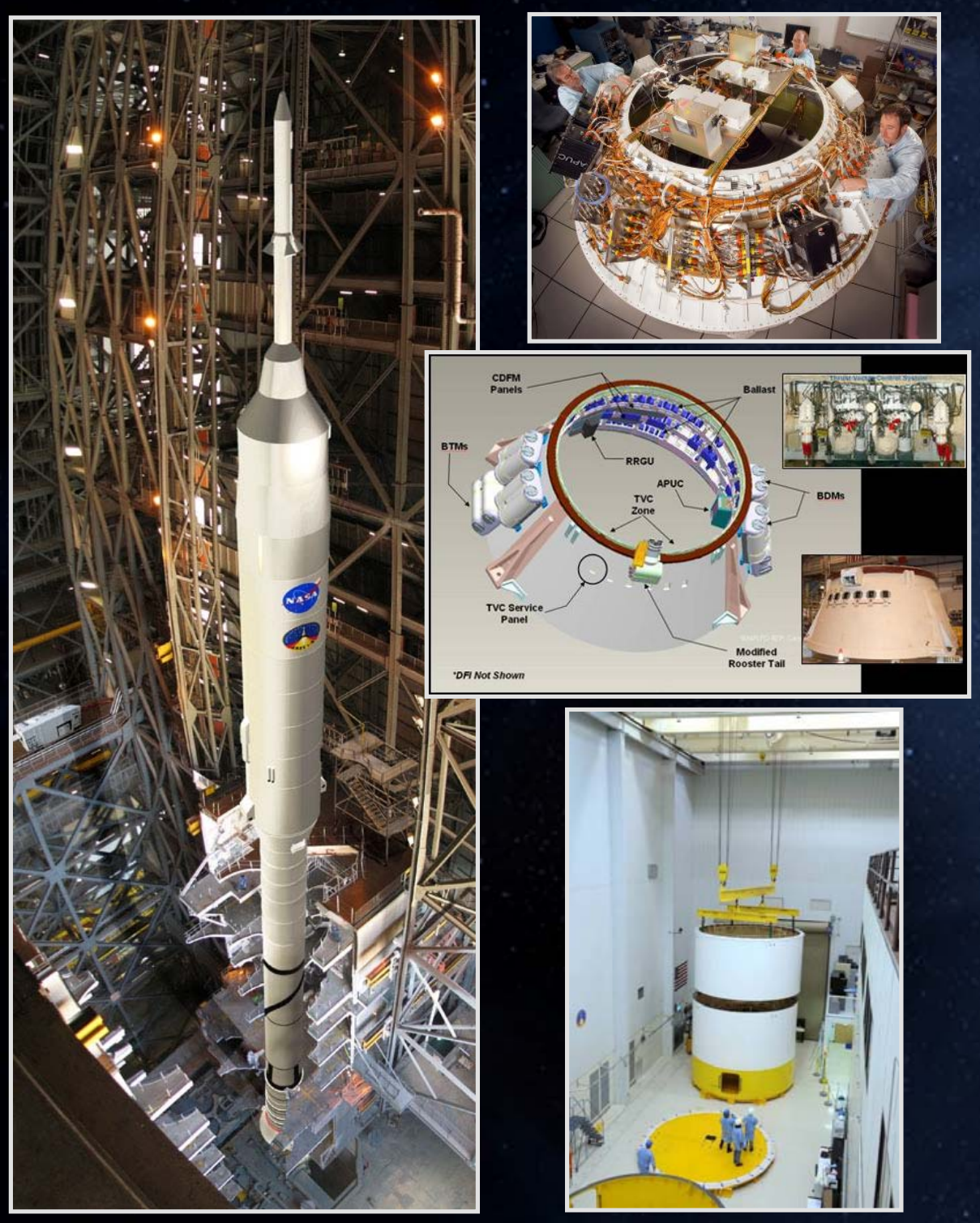

First Ares I flight test (uncreyed)

Will demonstrate ascent, separation, roll control, recovery, and ground capabilities

$\checkmark$ Uses off-the-shelf, active, and simulator hardware

- First stage propulsion, avionics, and roll control active systems

- First stage forward structures, upper stage, Orion crew exploration vehicle, and Launch Abort System (LAS) instrumented mass simulator hardware

Holding flight hardware deliveries to April 2009 launch date

$>$ Launch date could be delayed due to availability of Mobile Launcher 


\section{Upcoming Activities}

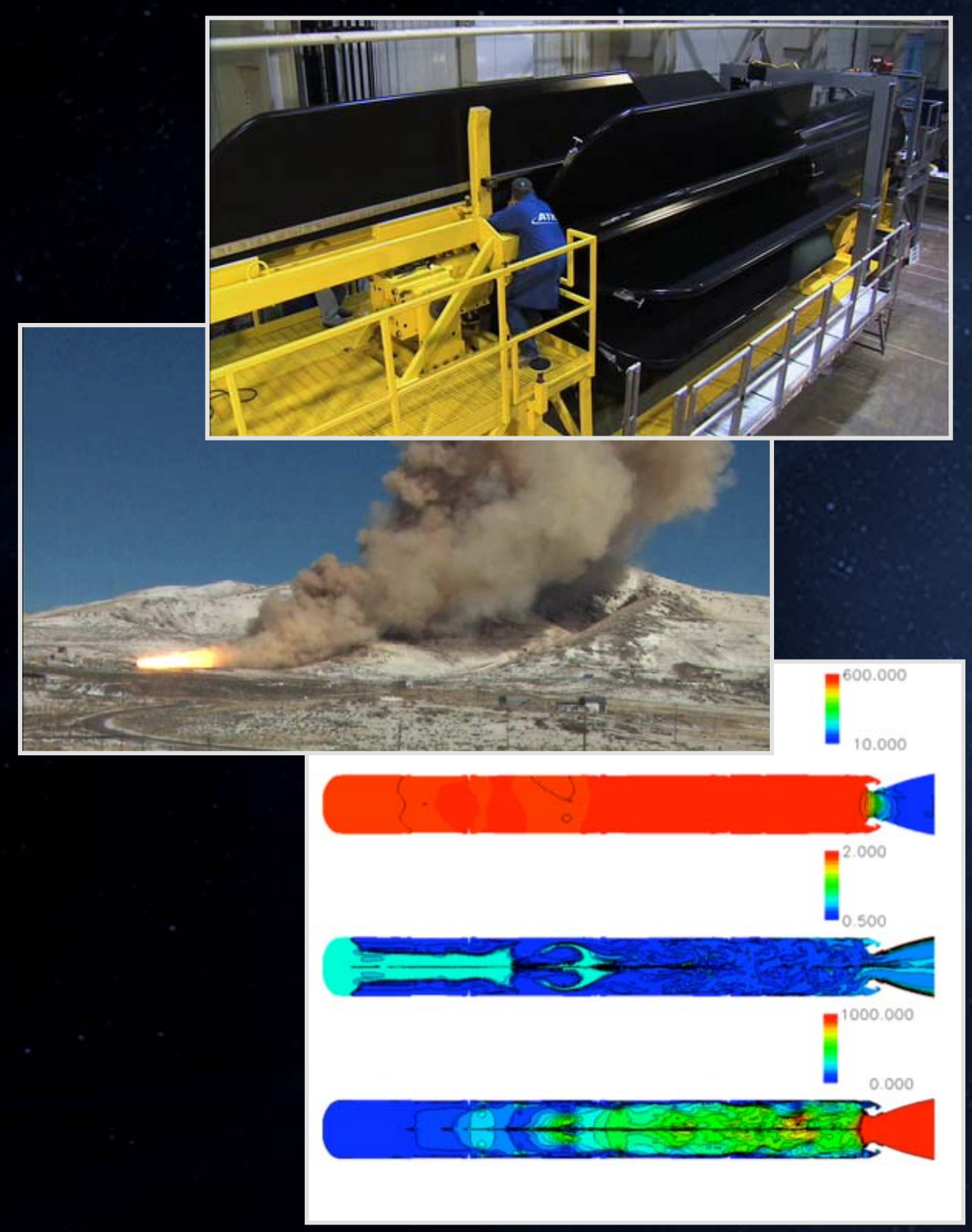

First 5-segment solid rocket unotor for Ares vehicles will be tested at ATr's Launch Systems in 2009

- Hardware already in fabrication

- Shuttle processes improved for safety and efficiency

- Data from test will inform future 5-segment motor designs

\section{First stage thrust oscillation}

- 'Developing design mitigation strategies to overcome first stage structure oscillation generated by propellant harmonics

- First Stage Element Office working with MSFC Engineering Directorate and Orion Project Office

- Mitigation to be identified by conclusion of Ares I PDR

- Additional data to be collected during Ares I-X flight test and upcoming Shuttle flights (gathering thrust oscillation data on Shuttle) 


\section{Ares V Cargo Launch Vehicle}

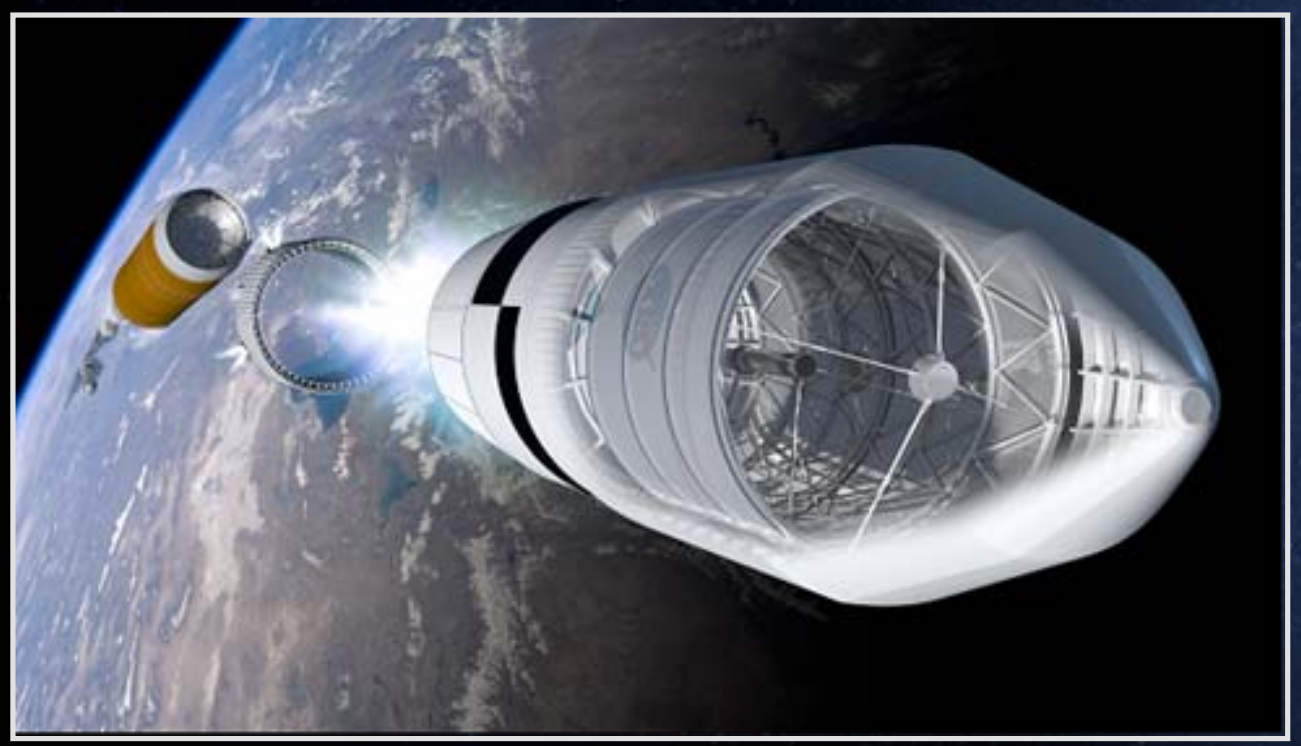

NASA has begun preliminary concept work on vehicle

Focused on design of EDS, payload shroud, core stage, and RS-68 core stage engines

Recent point-of-departure updated for additional performance margin using an additional RS-68 and an added 1/2 segment on the first stage

Shroud size dictated by eventual size of Altair lunar lander

Also investigating alternate uses for Ares $\mathrm{V}$ not related to human space exploration

- Very large (8-meter aperture) science telescopes in low-Earth or Lagrange (L2) orbits

- Capabilities could exceed Hubble by an order of magnitude 


\section{Summary}

$\diamond$ Ares Projects making great strides toward building a new generation of launch vehicles

$\checkmark$ Support ISS operations and human exploration of Moon and other destinations

Ares I-X flight test in 2009

$\checkmark$ Additional testing and development work in progress

Ares launch vehicles continue on schedule to fulfill this strategic capability for the future

- Capabilities will develop in environment of increasing challenges

$\checkmark$ NASA transitioning from performing space operations to expanding the Nation's frontiers

\section{Questions?}

www.nasa.gov/ares 